\title{
Metazoan gill parasites of the Atlantic bluefin tuna Thunnus thynnus (Linnaeus) (Osteichthyes: Scombridae) from the Mediterranean and their possible use as biological tags
}

\author{
Jacopo Culurgioni ${ }^{1 *}$, Salvatore Mele ${ }^{2 *}$, Paolo Merella ${ }^{2}$, Piero Addis ${ }^{1}$, Vincenza Figus ${ }^{1}$, Angelo Cau ${ }^{1}$, \\ Firdes Saadet Karakulak ${ }^{3}$ and Giovanni Garippa ${ }^{2}$
}

\author{
${ }^{1}$ Department of Life and Environmental Sciences, University of Cagliari, Italy; \\ ${ }^{2}$ Parasitology and Parasitic Diseases, Department of Veterinary Medicine, University of Sassari, Italy; \\ ${ }^{3}$ Faculty of Fisheries, Istanbul University, Laleli-Istanbul, Turkey \\ *These authors contributed equally to this work
}

\begin{abstract}
The gills of 63 specimens of the Atlantic bluefin tuna Thunnus thynnus (Linnaeus) (Osteichthyes: Scombridae) from three localities of the Mediterranean (Sardinian, Tyrrhenian and Levantine Seas) were examined for metazoan parasites. The parasite fauna of T. thynnus from the Sea of Sardinia included 11 species: five didymozoid trematodes, three capsalid and one hexostomid monogeneans, and one caligid and one pseudocycnid copepods. Four didymozoids were found in fish from the Levantine Sea and only one didymozoid was recorded in fish from the Tyrrhenian Sea. Dividing the hosts into four size-groups (small, medium-sized, large and extra large), the pairwise comparison of prevalence and mean abundance of the new and literary data) showed differences according to host size. The differences in the composition of the parasitic faunas and in the prevalence of parasites, observed between the small tunas from the Tyrrhenian Sea and the medium-sized tunas from the Adriatic Sea, Levantine Sea and the North-East (NE) Atlantic Ocean, indicated that these groups form discrete units. The parasite fauna of the large tunas from the Sea of Sardinia is the richest among the bluefin tuna populations of the Mediterranean and the NE Atlantic, due to the presence of species not found elsewhere in bluefin tunas, such as Caligus coryphaenae Steenstrup et Lütken, 1861, Capsala magronum (Ishii, 1936) and C. paucispinosa (Mamaev, 1968). This fact and the prevalence of some parasites of this group (lower than those of medium-sized fish from the NE Atlantic and higher than the small and medium-sized tunas from the Mediterranean) suggest that the large-sized tuna group in the western Mediterranean is formed by Mediterranean resident tunas (poorly infected), and by tunas migrating from the Atlantic Ocean (heavily infected).
\end{abstract}

Keywords: Copepoda, Didymozoidae, Monogenea, marine fish, bioindicators, fish parasites, Sea of Sardina, Levantine Sea

The Atlantic bluefin tuna Thunnus thynnus (Linnaeus) (Osteichthyes: Scombridae) is a pelagic fish inhabiting the Central and North-East (NE) Atlantic Ocean, including the Mediterranean Sea, and the Central and North-West (NW) Atlantic Ocean, from the Gulf of Mexico to Newfoundland (Fromentin and Powers 2005). This species is one of the most important and valuable finfish worldwide, with $32244 \mathrm{t}$ landed in 2007 (about 490 million of US \$), of which 26059 t $(81 \%)$ captured in the Mediterranean Sea (FAO 2010).

The Atlantic bluefin tuna is a large top-predator, which has long been a significant food supply for many Mediterranean coastal communities, where is still captured by traditional trap fisheries (Addis et al. 2008, 2012). Currently, the international scientific community recognises the existence of two bluefin tuna populations, corresponding to the two major reproductive areas for the species, i.e. the Mediterranean Sea and the Gulf of Mexico. This hypothesis also justifies the two-stock premise ('western' and 'eastern') adopted by the International Commission for the Conservation of the Atlantic Tunas (ICCAT) with management purposes.

At present, the Atlantic bluefin tuna is considered overexploited and it is included in a multiannual recovery plan by ICCAT (ICCAT rec. 08-05/2008 and EC n. 1559/2007; Damanaki 2010). The ecology of this species is complex, because of its migratory nature, wide distribution, natal homing behaviour, and other features such as the variety of diet and the wide range of depth and temperature it tolerates (Rooker et al. 2007).

Parasitological studies on the Atlantic bluefin tuna and other bluefin tunas, i.e. the southern bluefin tuna, Thunnus maccoyii (Castelnau), and the Pacific bluefin tuna, Thunnus orientalis (Temminck et Schlegel), deal mainly with

Address for correspondence: J. Culurgioni, Department of Life and Environmental Sciences, University of Cagliari, Via T. Fiorelli 1, 09126 Cagliari, Italy. Phone: +39 070675 8057; Fax: +39 070675 8022; E-mail: jculurgioni@gmail.com 
taxonomy (Ariola 1902, Ishii 1935, Cressey and Cressey 1980), the effects of parasitic infections in cage-reared fish (Mladineo et al. 2008, Ruiz de Ybañez et al. 2011), or the use of parasites as biological tags (MacKenzie 1983, Rodríguez-Marín et al. 2008, Mladineo et al. 2010). The research on large tunas is hampered by the high value of fish; therefore, the studies on the use of parasites as tags consider mainly examination of gills, head and viscera, because of their limited (or null) commercial value (Lardeaux 1982, Lester et al. 1985, Jones 1991, RodríguezMarín et al. 2008).

The aim of this paper is to describe the metazoan gill parasites of T. thynnus from the Western and Eastern Mediterranean, comparing the results with data on T. thynnus from the Central Mediterranean and the Atlantic Ocean, and on T. maccoyii from the Indian Ocean and T. orientalis from the Pacific Ocean, with the goal of evaluating the use of parasites as tags for studies on host biology and ecology.

\section{MATERIALS AND METHODS}

Sixty-three Atlantic bluefin tunas, Thunnus thynnus, caught off Sardinia (Western Mediterranean) in 2006 and 2007, were examined for parasites (Table 1): 49 adults (30 in May-June 2006 and 19 in May-June 2007) caught by traditional trap fishery 'tonnara' off the Isle of San Pietro $\left(39^{\circ} 11^{\prime} \mathrm{N} ; 8^{\circ} 18^{\prime} \mathrm{E}\right.$, Sea of Sardinia), and four young-of-the-year caught in September 2006 by trolling off the Isle of Tavolara $\left(40^{\circ} 50^{\prime} \mathrm{N}\right.$; $9^{\circ} 57^{\prime} \mathrm{E}$, Tyrrhenian Sea). In addition, ten juveniles caught in May-June 2007 by trolling in the Levantine Sea (Eastern Mediterranean) were examined (Table 1). After landing, tunas were measured and weighed; the gills were extracted, labelled, stored individually in plastic bags and frozen at $-20^{\circ} \mathrm{C}$.

In the laboratory, the gills were defrosted and examined by naked eye and under a stereomicroscope for metazoan parasites. The location of the parasites and possible pathological alterations were recorded according to Mele et al. (2012), differentiating holobranchs left and right 1 to 4 (from the anterior-external to the posterior-internal); the microhabitat of each holobranch was divided into: gill rakers, gill arch, inner and outer surfaces of gill hemibranchs (Fig. 1).

Parasites were counted and stored in 70\% ethanol. Monogeneans were identified following Palombi (1949) and Chisholm and Whittington (2007); didymozoids according to Ishii (1935), Guiart (1938), Yamaguti (1970), Pozdnyakov (1990) and Pozdnyakov and Gibson (2008); and copepods following Cressey and Cressey (1980) and Kabata (1992).

Prevalence (P\%), mean abundance (MA) and mean intensity (MI) of each parasite species were calculated according to Bush et al. (1997). The confidence intervals for prevalences were calculated with the Sterne exact method and the differences between prevalences were evaluated with Fisher's exact test. The confidence intervals for the mean abundances and mean intensities were calculated with the bias-corrected and accelerated Efron-Tibshirani bootstrap, and their differences evaluated with the bootstrap rank Welch test (Reiczigel and Rózsa 2005). Statistical descriptors were computed and analyses carried out
Table 1. Samples of Thunnus thynnus examined in the present study.

\begin{tabular}{|c|c|c|c|c|c|c|}
\hline Locality & Month & Year & $\mathrm{n}$ & FL & TW & Size group \\
\hline $\begin{array}{l}\text { Levantine Sea } \\
\text { (EM) }\end{array}$ & May-June & 2007 & 10 & $78-100$ & $9-19$ & Medium-sized \\
\hline $\begin{array}{l}\text { Sea of Sardinia } \\
\text { (WM) }\end{array}$ & May-June & 2006 & 30 & $120-227$ & $32-192$ & $\begin{array}{l}\text { Large }(\mathrm{n}=25) ; \\
\text { Extra-large } \\
(\mathrm{n}=5)\end{array}$ \\
\hline & May-June & 2007 & 19 & $106-148$ & $23-58$ & Large \\
\hline $\begin{array}{l}\text { Tyrrhenian Sea } \\
\text { (WM) }\end{array}$ & September & 2006 & 4 & $27-31$ & $0.4-1$ & Small \\
\hline
\end{tabular}

EM - Eastern Mediterranean; FL - fork length (range in cm); TW - total weight (range in kg); WM - Western Mediterranean.
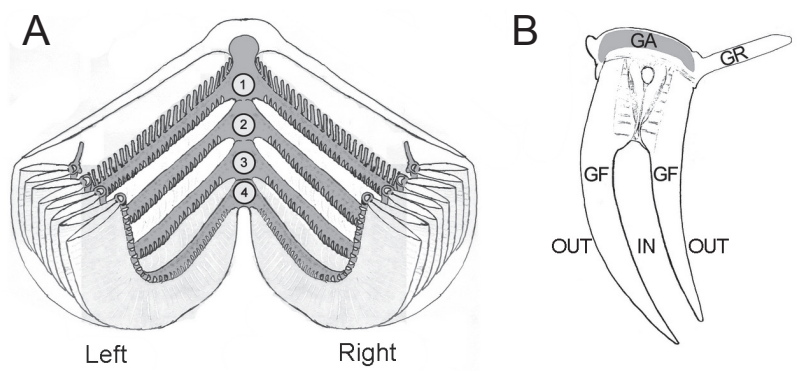

Fig. 1. Schematic drawing of the gills of Thunnus thynnus. $\mathbf{A}$-holobranchs 1 to 4 ; $\mathbf{B}$ - transverse section of the holobranch. Abbreviations: GA - gill arch; GF - gill filament; GR - gill raker; IN - inner margin of gill filaments; OUT - outer margin of gill filaments.

with the free software Quantitative Parasitology 3.0 (Reiczigel and Rózsa 2005).

Parasite site-specificity was tested according to: (i) left and right gills; and (ii) gill rakers, arch, and inner and outer surfaces of hemibranchs (grouping corresponding regions of holobranchs as defined above). The dominant species of the parasite assemblages was evaluated with the Berger-Parker dominance index (d) (Magurran 2004). The levels of infection with each parasite species were calculated dividing the hosts into four groups according to size: (1) small, fork length (FL) $<50 \mathrm{~cm}$; (2) medium-sized, FL $=51-100 \mathrm{~cm}$; (3) large, $\mathrm{FL}=101-150 \mathrm{~cm}$; and (4) extra large, $\mathrm{FL}=151-230 \mathrm{~cm}$. Samples from the Western Mediterranean comprised the groups 1 (Tyrrhenian Sea), 3 and 4 (Sea of Sardinia), and all fish from the Eastern Mediterranean (Levantine Sea) were of the group 2 (Table 1).

Parasite fauna dissimilarity was evaluated with the Marczewski-Steinhaus distance and the Bray-Curtis index, calculated using the R-software ('cc' and '-1' methods of the 'betadiver' function of the 'vegan' library, respectively, R Development Core Team 2012). These indices are complementary measures of the Jaccard and Sorensen similarity indices, respectively (Chao et al. 2005); the latter indices are almost equivalent, except that the second gives double weight to the positive co-occurrences (Dalirsefat et al. 2009). The use of their complementary measures allows forming agglomerative (bottom up) hierarchical trees, in which the groups with the lowest dissimilarity cluster to the bottom and the dimension of branches can be meaningfully associated with the distance between clusters (Bakus 2007). 
Table 2. Prevalence (\%) (upper row) and mean abundance (lower row) of the gill parasites of Thunnus thynnus with 95\% confidence intervals in parentheses stratified by host size and locality. Greek letters indicate significant differences between pairs of samples $(\mathrm{p} \leq 0.05)$.

\begin{tabular}{|c|c|c|c|c|c|c|}
\hline Host size group & Small & & Medium-sized & & Large & Extra-large \\
\hline Region & $\begin{array}{c}\text { Tyrrhenian Sea } \\
\text { WM }\end{array}$ & $\begin{array}{l}\text { Adriatic Sea } \\
\text { EM }\end{array}$ & $\begin{array}{c}\text { Levantine Sea } \\
\text { EM }\end{array}$ & NE Atlantic & $\begin{array}{l}\text { Sea of Sardinia } \\
\text { WM }\end{array}$ & $\begin{array}{c}\text { Sea of Sardinia } \\
\text { WM }\end{array}$ \\
\hline $\begin{array}{l}\text { Parasite/ } \\
\text { Source }\end{array}$ & $\begin{array}{l}\text { Present study } \\
\quad(\mathrm{n}=4)\end{array}$ & $\begin{array}{l}\text { Mladineo et al. } \\
\qquad(2008)\end{array}$ & $\begin{array}{l}\text { Present study } \\
\quad(\mathrm{n}=10)\end{array}$ & $\begin{array}{l}\text { Rodríguez-Marín } \\
\text { et al. (2008) }\end{array}$ & $\begin{array}{l}\text { Present study } \\
\quad(\mathrm{n}=44)\end{array}$ & $\begin{array}{l}\text { Present study } \\
\quad(\mathrm{n}=5)\end{array}$ \\
\hline \multicolumn{7}{|l|}{ Monogenea } \\
\hline $\begin{array}{l}\text { Capsala magronum } \\
\text { (Ishii, 1936) }\end{array}$ & $\begin{array}{l}0 \\
0\end{array}$ & $\begin{array}{l}0 \\
0\end{array}$ & $\begin{array}{c}0(0-29) \\
0\end{array}$ & $\begin{array}{l}0 \\
0\end{array}$ & $\begin{array}{c}2(0.1-12) \\
0.02(0-0.07)\end{array}$ & $\begin{array}{l}0 \\
0\end{array}$ \\
\hline $\begin{array}{l}\text { Capsala onchidiocotyle } \\
\text { (Setti, 1899) }\end{array}$ & $\begin{array}{l}0 \\
0\end{array}$ & $\begin{array}{c}0^{\alpha} \\
0\end{array}$ & $\begin{array}{c}0(0-29) \\
0\end{array}$ & $\begin{array}{l}5^{\alpha} \\
0.3\end{array}$ & $\begin{array}{c}2(0.1-12) \\
0.02(0-0.07)\end{array}$ & $\begin{array}{l}0 \\
0\end{array}$ \\
\hline $\begin{array}{l}\text { Capsala paucispinosa } \\
\text { (Mamaev, 1968) }\end{array}$ & $\begin{array}{l}0 \\
0\end{array}$ & $\begin{array}{l}0 \\
0\end{array}$ & $\begin{array}{c}0(0-29) \\
0\end{array}$ & $\begin{array}{l}0 \\
0\end{array}$ & $\begin{array}{c}2(0.1-12) \\
0.02(0-0.07)\end{array}$ & $\begin{array}{l}0 \\
0\end{array}$ \\
\hline $\begin{array}{l}\text { Hexostoma thynni } \\
\text { Rafinesque, } 1815\end{array}$ & $\begin{array}{c}0^{\alpha} \\
0\end{array}$ & $\begin{array}{l}2^{\gamma, \varepsilon, \eta} \\
0.02\end{array}$ & $\begin{array}{c}0(0-29)^{\beta, \zeta} \\
0\end{array}$ & $\begin{array}{c}61^{\alpha, \beta, \gamma, \delta} \\
1.2^{2}\end{array}$ & $\begin{array}{l}27(16-4)^{\delta, \varepsilon} \\
0.8(0.4-1.7)\end{array}$ & $\begin{array}{c}60^{\zeta, \eta} \\
1.6\end{array}$ \\
\hline \multicolumn{7}{|l|}{ Digenea } \\
\hline $\begin{array}{l}\text { Copiatestes thyrsitae } \\
\text { Crowcroft, } 1948\end{array}$ & $\begin{array}{l}0 \\
0\end{array}$ & $\begin{array}{l}0 \\
0\end{array}$ & $\begin{array}{c}0(0-29) \\
0\end{array}$ & $\begin{array}{c}2 \\
0.02\end{array}$ & $\begin{array}{c}0(0-9) \\
0\end{array}$ & $\begin{array}{l}0 \\
0\end{array}$ \\
\hline $\begin{array}{l}\text { Didymocylindrus filiformis } \\
\text { Ishii, } 1935\end{array}$ & $\begin{array}{l}0 \\
0\end{array}$ & $\begin{array}{l}0.6 \\
0.01\end{array}$ & $\begin{array}{c}0(0-29) \\
0\end{array}$ & $\begin{array}{l}0 \\
0\end{array}$ & $\begin{array}{c}0(0-9) \\
0\end{array}$ & $\begin{array}{l}0 \\
0\end{array}$ \\
\hline $\begin{array}{l}\text { Didymocystis reniformis } \\
\text { Ariola, } 1902^{1}\end{array}$ & $\begin{array}{l}0 \\
0\end{array}$ & $\begin{array}{l}24^{\alpha} \\
1.3\end{array}$ & $\begin{array}{c}0(0-29) \\
0\end{array}$ & $\begin{array}{l}18^{\beta} \\
1.1\end{array}$ & $\begin{array}{l}2(0.1-12)^{\alpha, \beta} \\
0.11(0-0.34)\end{array}$ & $\begin{array}{l}0 \\
0\end{array}$ \\
\hline $\begin{array}{l}\text { Didymocystis sp. } 3 \text { sensu } \\
\text { Rodríguez-Marín et al., (2008) }\end{array}$ & $\begin{array}{l}0 \\
0\end{array}$ & $\begin{array}{c}0^{\alpha} \\
0\end{array}$ & $\begin{array}{c}0(0-29) \\
0\end{array}$ & $\begin{array}{l}19^{\alpha, \beta} \\
0.95\end{array}$ & $\begin{array}{c}0(0-9)^{\beta} \\
0\end{array}$ & $\begin{array}{l}0 \\
0\end{array}$ \\
\hline $\begin{array}{l}\text { Didymosulcus wedli } \\
\text { (Ariola, 1902) }\end{array}$ & $\begin{array}{c}0^{\alpha, \beta, \gamma, \delta} \\
0^{\alpha}\end{array}$ & $\begin{array}{c}62^{\alpha, \zeta} \\
29\end{array}$ & $\begin{array}{l}50(22-78)^{\varepsilon} \\
2.8(0.8-8.1)\end{array}$ & $\begin{array}{c}92^{\beta, \varepsilon, \zeta, \eta} \\
22^{2}\end{array}$ & $\begin{array}{l}75(60-86)^{\gamma, \eta} \\
6(4-9)^{\alpha}\end{array}$ & $\begin{array}{c}100^{\delta} \\
12\end{array}$ \\
\hline $\begin{array}{l}\text { Didymosulcus sp. } 2 \text { sensu } \\
\text { Rodríguez-Marín et al., (2008) }\end{array}$ & $\begin{array}{c}100^{\alpha, \beta, \gamma, \delta, \varepsilon} \\
11^{\alpha}\end{array}$ & $\begin{array}{c}0^{\beta, \zeta, \eta, 1} \\
0\end{array}$ & $\begin{array}{l}20(4-55)^{\alpha, \zeta} \\
1.7(0-6.5)^{\alpha}\end{array}$ & $\begin{array}{c}23^{\gamma, \eta, \theta} \\
1.2\end{array}$ & $\begin{array}{l}5(0.8-16)^{\delta, \theta, 1} \\
0.05(0-0.11)\end{array}$ & $\begin{array}{l}0^{\varepsilon} \\
0\end{array}$ \\
\hline $\begin{array}{l}\text { Didymozoon longicolle } \\
\text { Ishii, } 1935\end{array}$ & $\begin{array}{l}0 \\
0\end{array}$ & $\begin{array}{c}1.1 \\
0.02\end{array}$ & $\begin{array}{c}0(0-29) \\
0\end{array}$ & $\begin{array}{l}0 \\
0\end{array}$ & $\begin{array}{c}0(0-9) \\
0\end{array}$ & $\begin{array}{l}0 \\
0\end{array}$ \\
\hline $\begin{array}{l}\text { Didymozoon pretiosus } \\
\text { Ariola, } 1902^{2}\end{array}$ & $\begin{array}{l}0 \\
0\end{array}$ & $\begin{array}{c}0^{\alpha, \beta, \delta} \\
0\end{array}$ & $\begin{array}{l}20(4-55)^{\alpha} \\
0.6(0-2.1)\end{array}$ & $\begin{array}{c}19^{\beta, \gamma} \\
2.3\end{array}$ & $\begin{array}{c}7(2-19)^{\gamma, \delta} \\
0.2(0.05-0.52)\end{array}$ & $\begin{array}{l}0 \\
0\end{array}$ \\
\hline $\begin{array}{l}\text { Kollikerioides apicalis } \\
\text { Yamaguti, } 1970\end{array}$ & $\begin{array}{l}0 \\
0\end{array}$ & $\begin{array}{l}11^{\alpha, \beta} \\
0.33\end{array}$ & $\begin{array}{c}0(0-29) \\
0\end{array}$ & $\begin{array}{c}0^{\alpha} \\
0\end{array}$ & $\begin{array}{c}0(0-9)^{\beta} \\
0\end{array}$ & $\begin{array}{l}0 \\
0\end{array}$ \\
\hline $\begin{array}{l}\text { Wedlia bipartita } \\
\text { Ariola, } 1902\end{array}$ & $\begin{array}{l}0 \\
0\end{array}$ & $\begin{array}{c}0^{\alpha} \\
0\end{array}$ & $\begin{array}{c}10(0.5-45)^{\alpha, \beta} \\
0.1(0-0.3)\end{array}$ & $\begin{array}{c}0^{\beta} \\
0\end{array}$ & $\begin{array}{c}2(0.1-12) \\
0.02(0-0.07)\end{array}$ & $\begin{array}{l}0 \\
0\end{array}$ \\
\hline \multicolumn{7}{|l|}{ Copepoda } \\
\hline $\begin{array}{l}\text { Caligus coryphaenae } \\
\text { Steenstrup et Lütken, } 1861\end{array}$ & $\begin{array}{l}0 \\
0\end{array}$ & $\begin{array}{l}0 \\
0\end{array}$ & $\begin{array}{c}0(0-29) \\
0\end{array}$ & $\begin{array}{l}0 \\
0\end{array}$ & $\begin{array}{c}2(0.1-12) \\
0.02(0-0.07)\end{array}$ & $\begin{array}{l}0 \\
0\end{array}$ \\
\hline $\begin{array}{l}\text { Euryphorus brachypterus } \\
\text { (Gerstaecker, 1853) }\end{array}$ & $\begin{array}{l}0 \\
0\end{array}$ & $\begin{array}{l}0 \\
0\end{array}$ & $\begin{array}{c}0(0-29) \\
0\end{array}$ & $\begin{array}{c}2 \\
0.02\end{array}$ & $\begin{array}{c}0(0-9) \\
0\end{array}$ & $\begin{array}{l}0 \\
0\end{array}$ \\
\hline $\begin{array}{l}\text { Pseudocycnus appendiculatus } \\
\text { Heller, } 1865\end{array}$ & $\begin{array}{l}0 \\
0\end{array}$ & $\begin{array}{c}0^{\alpha, \gamma, \delta} \\
0\end{array}$ & $\begin{array}{c}0(0-29) \\
0\end{array}$ & $\begin{array}{c}29^{\alpha, \beta} \\
0.58\end{array}$ & $\begin{array}{c}9(3-21)^{\beta, \gamma} \\
0.09(0.02-0.18)\end{array}$ & $\begin{array}{l}40^{\delta} \\
1.2\end{array}$ \\
\hline
\end{tabular}

${ }^{1}$ species synonymised with Didymocystis semiglobularis Ishii, $1935 ;{ }^{2}$ species synonymised with Didymozoon filicolle Ishii, 1935 ; EM - Eastern Mediterranean; WM - Western Mediterranean.

\section{RESULTS}

In the present study, 11 parasite species/taxa (all adults) were found in the gills of Thunnus thynnus from the Eastern and Western Mediterranean (Table 2). Most of the parasites were didymozoid trematodes $(88.2 \%$ of all specimens; $\mathrm{n}=502$ ) belonging to five species: Didymocystis reniformis, Didymosulcus wedli, Didymosulcus sp. 2 sensu, Didymozoon pretiosus and Wedlia bipartita. Four monogenean species (9.6\% of all specimens): Capsala magronum; C. onchidiocotyle; C. paucispinosa and Hexostoma thynni; and two copepod species $(2.2 \%$ of all specimens): Caligus coryphaenae and Pseudocycnus appendiculatus were also recovered. All parasite species listed above were found in the sample of large fish from the Sea of Sardinia, three species $(D$. wedli, H. thynni and
P. appendiculatus) in the sample of extra large fish from the same locality, whereas only Didymosulcus sp. 2 was found in the sample of small fish from the Tyrrhenian Sea. Four didymozoid species (Didymosulcus wedli, Didymosulcus sp. 2, Didymozoon pretiosus and W. bipartita) were found in the medium-sized fish from the Levantine Sea. Didymosulcus wedli was the dominant species in the parasite assemblages in larger fish (medium-sized group, $\mathrm{d}=0.54$; large size group, $\mathrm{d}=0.83$; and extra large size group, $\mathrm{d}=0.81$ ), whereas Didymosulcus sp. 2 was the only species found in the small fish (small size group, $\mathrm{d}=1.00$ ).

Overall, $84 \%$ of the gills examined harboured metazoan parasites. Table 2 shows the parasite prevalence in the four Mediterranean host size-groups sampled in the present study in comparison with these in medium-sized T. thynnus sampled in the Adriatic Sea by Mladineo et 
Table 3. Records of gill parasites in the three species of bluefin tuna, Thunnus spp. from different regions.

\begin{tabular}{|c|c|c|c|c|c|c|c|}
\hline \multirow{2}{*}{$\begin{array}{l}\text { Parasite/Host } \\
\text { Region }\end{array}$} & \multirow{2}{*}{$\begin{array}{c}\text { Thunnus } \\
\text { maccoyii } \\
\text { IO }\end{array}$} & \multirow{2}{*}{$\begin{array}{c}\begin{array}{c}\text { Thunnus } \\
\text { orientalis }\end{array} \\
\text { PO }\end{array}$} & \multicolumn{5}{|c|}{ Thunnus thynnus } \\
\hline & & & NE AO & NW AO & EM & $\mathrm{CM}$ & WM \\
\hline \multicolumn{8}{|l|}{ Monogenea } \\
\hline Capsala interrupta (Monticelli, 1891) & - & - & - & - & - & - & 6 \\
\hline Capsala magronum (Ishii, 1936) & - & 6 & 2 & - & - & - & * \\
\hline Capsala maccallumi Price, 1939 & - & - & - & 6 & - & - & - \\
\hline Capsala onchidiocotyle (Setti, 1899) & 7 & - & 9 & - & - & - & $6, *$ \\
\hline Capsala paucispinosa (Mamaev, 1968) & 6 & - & - & - & - & - & * \\
\hline Hexostoma grossum (Goto, 1894) & - & 2 & - & - & - & - & - \\
\hline Hexostoma thynni Rafinesque, 1815 & 7 & - & 9 & - & - & 8,11 & $2, *$ \\
\hline \multicolumn{8}{|l|}{ Digenea } \\
\hline Copiatestes thyrsitae Crowcroft, 1948 & - & - & 9 & - & - & - & - \\
\hline Didymocylindrus filiformis Ishii, 1935 & - & 2 & - & - & - & 8,11 & - \\
\hline Didymocystis reniformis Ariola, $1902^{1}$ & - & 2,5 & 9 & - & - & 8,11 & $2, *$ \\
\hline Didymocystis sp. 3 sensu Rodríguez-Marín et al., (2008) & - & - & 9 & - & - & - & - \\
\hline Didymoproblema fusiforme Ishii, 1935 & - & 2 & - & - & - & - & - \\
\hline Didymosulcus crassa (Ishii, 1935) & - & 2 & - & - & - & - & - \\
\hline Didymosulcus soleiformis Ishii, 1935 & - & 2 & - & - & - & - & - \\
\hline Didymosulcus wedli (Ariola, 1902) & - & 2,5 & 9 & - & $*$ & 8,10 & $2, *$ \\
\hline Didymosulcus sp. 2 sensu Rodríguez-Marín et al., (2008) & - & - & 9 & - & $*$ & - & * \\
\hline Didymozoon longicolle Ishii, 1935 & - & 2 & - & - & - & 8,10 & - \\
\hline Didymozoon pretiosus Ariola, $1902^{2}$ & - & 2 & 9 & - & * & - & $2, *$ \\
\hline Kollikerioides apicalis Yamaguti, 1970 & - & - & - & - & - & 8,10 & - \\
\hline Lobatozoum multisacculatum Ishii, 1935 & - & 2 & - & - & - & 8,10 & - \\
\hline Wedlia bipartita Ariola, 1902 & - & - & 2 & - & * & 2 & $2, *$ \\
\hline Wedlia reniformis Ishii, 1935 & - & 2,5 & - & - & - & - & - \\
\hline \multicolumn{8}{|l|}{ Copepoda } \\
\hline Caligus bonito Wilson, 1905 & - & 3 & - & 4 & - & - & - \\
\hline Caligus coryphaenae Steenstrup et Lütken, 1861 & - & 3 & - & 4 & - & - & * \\
\hline Caligus chiastos Lin et $\mathrm{Ho}, 2003$ & 7 & - & - & - & - & - & - \\
\hline Caligus productus Dana, 1852 & - & 3,4 & - & 4 & - & - & - \\
\hline Euryphorus brachypterus (Gerstaecker, 1853) & 7 & 3,4 & 9 & 3,4 & - & 10 & 1 \\
\hline Pseudocycnus appendiculatus Heller, 1865 & 7 & - & 9 & - & - & - & $1, *$ \\
\hline
\end{tabular}

Data from: 1 - Brian 1906; 2 - Silas 1962; 3 - Silas and Ummerkutty 1967; 4 - Cressey and Cressey 1980; 5 - Momoyama and Kobayashi 2004; 6 - Chisholm and Whittington 2007; 7 - Hayward et al. 2007; 8 - Mladineo et al. 2008; 9 - Rodríguez-Marín et al. 2008; 10 - Mladineo et al. 2011; * - present study; ${ }^{1}$ species synonymised with Didymocystis semiglobularis Ishii, $1935 ;{ }^{2}$ species synonymised with Didymozoon filicolle Ishii, 1935 ; CM - Central Mediterranean; EM - Eastern Mediterranean; IO - Indian Ocean; NE AO - North-East Atlantic Ocean; NW AO - North-West Atlantic Ocean; PO - Pacific Ocean; WM - Western Mediterranean.

al. (2008) and in the NE Atlantic by Rodríguez-Marín et al. (2008). Statistical comparisons revealed that most of the parasites of the medium-sized fish from the NE Atlantic (C. onchidiocotyle, D. reniformis, Didymocystis sp. 3 sensu Rodríguez-Marín et al. 2008, Didymosulcus sp. 2, D. wedli, D. pretiosus, H. thynni and P. appendiculatus) had significantly higher prevalence $(\mathrm{p}<0.05)$ than those in at least one of the Mediterranean groups (Table 2).

The prevalences of a number of parasites (D. reniformis, Didymosulcus sp. 2, D. wedli, D. pretiosus, H. thynni, Kollikerioides apicalis Yamaguti, 1970, P. appendiculatus and $W$. bipartita) showed differences between the Mediterranean groups. The prevalence of $D$. reniformis in the mediumsized fish from the Adriatic Sea was higher than that in the large fish from the Sea of Sardinia $(p=0.01)$, whereas that of Didymosulcus sp. 2 in the small fish from the Tyrrhenian Sea was higher than in the remaining groups $(\mathrm{p}<0.02)$.
The prevalence of $D$. wedli in the small fish from the Tyrrhenian Sea was lower than in the medium-sized fish from the Adriatic Sea and in the large and extra large fish from the Sea of Sardinia $(\mathrm{p}<0.02)$. The prevalence of D. pretiosus in the medium-sized fish from the Adriatic Sea was lower than in the medium-sized fish from the Levantine Sea and in the large fish from the Sea of Sardinia $(\mathrm{p}<0.01)$.

The prevalence of $H$. thynni in the extra large fish was higher than in the medium-sized fish from the Adriatic and Levantine Seas $(p<0.02)$ and that of $W$. bipartita in the medium-sized fish from the Levantine Sea was higher than in the medium-sized fish from the Adriatic Sea $(\mathrm{p}=0.05)$. No species showed significant differences in prevalence between the medium-sized (Levantine Sea) and large (Sea of Sardinia) fish, and between the medium-sized (NE Atlantic) and the extra large (Sea of Sardinia) fish. 


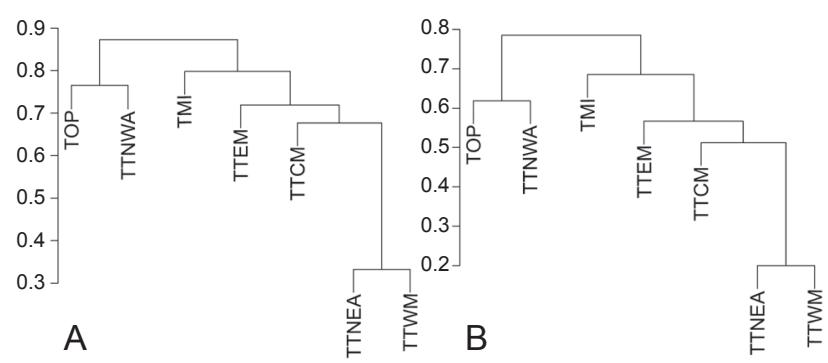

Fig. 2. Cluster dendrograms (group-average linkage method) of the gill parasite faunas of the three species of bluefin tunas from different localities: T. thynnus from the Eastern Mediterranean Sea (TTEM, present data), Central Mediterranean Sea (TTCM, data from literature), Western Mediterranean Sea (TTWM, data from literature and present data), and North-East and NorthWest Atlantic Ocean (TTNEA and TTNWA), T. maccoyii from the Indian Ocean (TMI), and T. orientalis from the Pacific Ocean (TOP), using Marczewski-Steinhaus (A) and Bray-Curtis (B) dissimilarity indices based on presence/absence data.

Mean abundance data for the parasites found in the four size-groups examined in the present study and for the medium-sized T. thynnus from the Adriatic Sea (Mladineo et al. 2008) and the NE Atlantic (Rodríguez-Marín et al. 2008) are provided in Table 2. The mean abundance of Didymosulcus sp. 2 was higher in the small fish from the Tyrrhenian Sea compared with that in the mediumsized fish from the Levantine Sea $(\mathrm{p}=0.02)$, and the mean abundance of $D$. wedli was lower in the small fish from the Tyrrhenian Sea compared with that in the large-sized fish from the Sea of Sardinia $(\mathrm{p}<0.01)$.

Table 3 summarises the published data on gill parasites of the three bluefin tuna species (T. maccoyii, T. orientalis and T. thynnus) in six geographical regions. A presence/ absence matrix based on these data and the present results allowed an evaluation of the dissimilarity between the parasite faunas of the gills of the three hosts from different localities.

Fig. 2 presents the results of the cluster analyses carried out using the two dissimilarity indices for the seven groups used in the analysis: (i) T. thynnus from the Eastern, Central and Western Mediterranean, and from the NE and NW Atlantic; (ii) T. maccoyii from the Indian Ocean; and (iii) T. orientalis from the Pacific Ocean. The parasite faunas of only two groups, i.e. T. thynnus from the NE Atlantic and the Western Mediterranean, exhibited very low levels of dissimilarity, whereas the faunas of the remaining five groups were largely dissimilar (Fig. 2).

Regarding the site-specificity of parasites on the gills, no significant differences in prevalence and mean intensity were observed between left and right gills. Fig. 3 shows the prevalence and mean intensity of the parasites in the different gill microhabitats. Hexostoma thynni was found on the gill filaments of the first and third holobranchs, with significantly higher prevalence on the outer margin of the gill filaments of the first holobranch than in all oth-

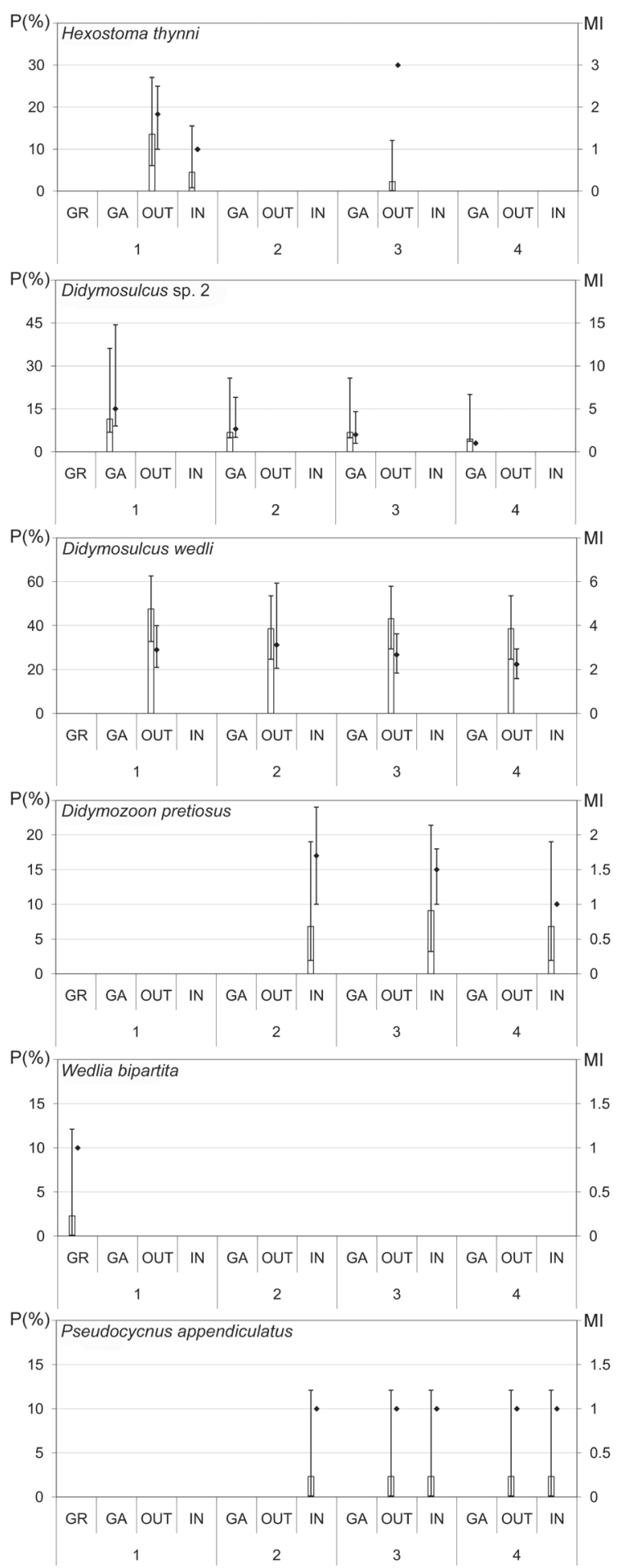

Fig. 3. Microhabitat selection of the metazoan parasites on the gills of Thunnus thynnus. Prevalence (P\%, bars), mean intensity (MI, diamonds), and 95\% confidence intervals (vertical lines). Numbers 1 to 4 indicate holobranchs. Abbreviations: GA- gill arch, GR - gill rakers; IN - inner margins of gill filaments; OUT - outer margins of gill filaments.

er microhabitats $(\mathrm{p}=0.03)$. Didymosulcus wedli showed a significantly high site-specificity for the outer margins of gill filaments of all holobranchs, as it was not detected 
in any other area of the gills $(\mathrm{p}<0.01)$. Capsalids, D. reniformis and Didymosulcus sp. 2, were located on the skin of the gill arches; $C$. coryphaenae was attached to the gill filaments of the 4th holobranch; D. pretiosus was found on the inner margin of the gill filaments of the 2nd to 4th holobranch; $W$. bipartita was located only on the gill rakers of the first holobranch; and $P$. appendiculatus was located on the gill filaments of the 2nd to 4th holobranchs. No severe pathological alterations associated with the presence of parasites were observed.

\section{DISCUSSION}

The metazoan parasite fauna of the gills of Thunnus thynnus includes a total of 22 species/taxa, with the richest fauna on fish from the Western Mediterranean (13 species), followed by the NE Atlantic (12 species), where most of the parasite species are shared (Table 3). The poorest parasite faunas of T. thynnus are from the NW Atlantic and the Eastern Mediterranean (5 and 4 parasite species, respectively), but this could also be related to the scarcity of studies in these two areas. Capsala interrupta (Monticelli, 1891) and Euryphorus brachypterus (Gerstaecker, 1853), previously reported in the Western Mediterranean (Table 3), were not found in the present study, whereas Caligus coryphaenae, C. magronum and Didymosulcus sp. 2 are reported for the first time in this area. Thunnus thynnus is a new host for C. paucispinosa.

Considering the other bluefin tuna species, T. thynnus shares five parasite species with $T$. maccoyii from the Indian Ocean, and 11 with $T$. orientalis from the Pacific Ocean. Because the three bluefin tuna species are geographically isolated, the presence of common parasites could be due to a common extinct ancestor in the geographical range of the host species (Chow and Kishino 1995), but also to the presence of other host species in the range of at least two bluefin tuna species, that allow the exchange of parasites (Aiken et al. 2007).

In fact, most of the parasites of bluefin tunas have also been recorded in other tuna species (e.g. C. magronum, C. maccallumi, C. paucispinosa, D. filiformis, Didymoproblema fusiforme Ishii 1935, D. wedli, E. brachypterus, H. thynni, Lobatozoum multisacculatum Ishii 1935 and Pseudocycnus appendiculatus) and other pelagic fish, e.g. D. reniformis, Didymosulcus soleiformis (Ishii, 1935), D. pretiosus and Wedlia reniformis Ishii, 1935 have been reported in Seriola quinqueradiata Temminck et Schlegel from the Pacific Ocean, W. bipartita in Seriola dumerilii (Risso) from the Mediterranean Sea, D. longicolle in S. quinqueradiata and Scomber japonicus Houttuyn from the Pacific Ocean, C. bonito and C. productus in scombrid fish from temperate and tropical oceans, respectively, Caligus chiastos Lin et Ho, 2003, C. coryphaenae and C. thyrsitae in several teleosts with a worldwide distribution (Silas 1962, Cressey and Cressey 1980, Mele et al. 2010, 2012).
On the other hand, some parasites seem to be strictly specific to T. orientalis, such as Didymosulcus crassa (Ishii, 1935) and Hexostoma grossum (Goto, 1894), and to T. thynnus, e.g. C. interrupta, Didymocystis sp. 3, and Didymosulcus sp. 2, although some of them could be more widely distributed among host species because they have been suggested as synonyms of other species (e.g. C. interrupta, C. maccallumi Price, 1939 and C. paucispinosa; H. grossum and H. thynni; Didymosulcus soleiformis Ishii, 1935 and Didymosulcus sp. 2; W. bipartita and W. reniformis Ishii, 1935) and thus require a taxonomic revision (Chisholm and Whittington 2007, Pozdnyakov and Gibson 2008).

Thunnus thynnus is a migratory fish that can travel long geographical distances, the giant tunas being able to cross the Atlantic Ocean (Rooker et al. 2007). The Mediterranean juvenile tunas (i.e. these of the small and the medium-sized group) seem to stay around their own breeding areas (Balearic, Ionian, Levantine and Tyrrhenian Seas), with local migrations to the feeding grounds in the Gulf of Lion, Adriatic Sea, Aegean Sea and Ligurian Sea, until reaching the size to migrate to the Atlantic Ocean (Karakulak and Oray 2009, Tudela et al. 2011, Sorell 2012, Rooker et al. 2003). These basins are characterised by different environmental conditions (Garibaldi and Caddy 1998) that can allow the occurrence of different parasite faunas. This can explain the differences between the small-sized group from the Tyrrhenian Sea and the medium-sized group from the Adriatic and Levantine Seas.

Similarly, differences in the environmental conditions between the Mediterranean and the NE Atlantic could explain the differences between the parasite assemblages of the juvenile tunas from the Mediterranean (i.e. smallsized group from the Tyrrhenian Sea and medium-sized group from the Adriatic and Levantine Seas) and the juvenile (medium-sized) fish from the NE Atlantic. Once mature (i.e. large and extra large size-group), during the warm season tunas go back from the Atlantic and Mediterranean feeding grounds to the spawning areas (Rooker et al. 2007). The parasite assemblage of the large tunas from the Sea of Sardinia has the higher species richness among the host populations of the Mediterranean and the NE Atlantic, due to the presence of $C$. coryphaenae, C. magronum and C. paucispinosa, species not recorded in the juvenile tunas in these regions.

These parasites are frequently found in other species of tuna, such as Auxis thazard (Lacépède), Euthynnus alletteratus (Rafinesque), Katsuwonus pelamis (Linnaeus), T. albacares (Bonnaterre), T. obesus (Lowe), from the tropical Atlantic area (Cressey and Cressey 1980, Chisholm and Whittington 2007), suggesting that the large T. thynnus infected by these parasites could originate from the tropical Atlantic Ocean. Unfortunately, no data are available on the gill parasites of T. thynnus from this area, although it is known that juveniles and adults 
of T. thynnus inhabit the waters along the NW African coasts and off Canary and Azores islands in winter (De la Serna et al. 2004).

Furthermore, the prevalence and mean abundance of the populations of several parasite species in the large tunas of the Sea of Sardinia were lower than those in juveniles from the NE Atlantic and higher than those in juveniles from the Mediterranean (e.g. D. wedli, D. pretiosus, $H$. thynni and $P$. appendiculatus). This suggests a composite school structure of this group, i.e. mainly formed by Mediterranean resident tunas (poorly infected), and by a number of tunas migrating from the Atlantic Ocean (highly infected). Although the small sample sizes for the small and extra large size-groups from the Western Mediterranean has likely influenced the richness of their parasite assemblages, thus biasing the results, it is important to state that the high prevalence of some parasites (D. wedli, H. thynni and P. appendiculatus) in the extra large fish from the Sea of Sardinia (similar to that of the medium-sized fish from the NE Atlantic) suggests that most of the these tunas may have migrated from the NE Atlantic area.

Several authors have described the use of parasites to separate populations and/or to study the migrations of T. thynnus (e.g. Walters 1980, MacKenzie 1983, Hogans 1985, Rodríguez-Marín et al. 2008). According to the general principle to select the parasites as tags illustrated by MacKenzie and Abaunza (1998), several didymozoid parasites of the Atlantic bluefin tuna can be considered reliable tags to follow its migrations, because: (i) they showed differences of infection between localities; (ii) they exhibit high site-specificity; (iii) they are permanent parasites (sensu Lester et al. 1985) and their remnants are recognizable in the host tissues well after their death; and (iv) the host cannot lose them when it migrates outside the endemic area of these parasites (Lester et al. 1985). Didymocystis sp. 3, Didymosulcus sp. 2 and K. apicalis may help distinguish T. thynnus from the endemic areas of these parasites (where each species has significantly higher prevalence) in the Atlantic Ocean, Western Mediterranean and Adriatic Sea. Moreover, D. pretiosus, $D$. reniformis and $W$. bipartita may help identify tunas migrating from the Mediterranean and the NE Atlantic to the
NW Atlantic, because these parasites have not so far been reported in tunas from the latter area.

Apart from didymozoids, P. appendiculatus can be used to distinguish bluefin tuna populations from the NE Atlantic and the Western Mediterranean from those of the Adriatic and Levantine Seas, where this species is absent. Some other parasites showed significant differences in infection levels between areas, but they do not fulfil the other requisites for biological tags, because they can be easily lost, and their microhabitat includes other locations apart from gills, e.g. the operculum and the surface of gill chamber for E. brachypterus, the mouth surface for capsalids and the digestive tract for C. thyrsitae (see Rodríguez-Marín et al. 2008). Finally, the lack of severe pathological alterations confirmed the results reported by Mladineo (2006) and Nowak et al. (2006), which makes the use of the gill parasites of the bluefin tuna as tags more reliable (MacKenzie and Abaunza 1998).

To conclude, the present study showed that the gills of tunas are infected by a rich metazoan parasite fauna that seems to be a promising tool to infer information on the host biology and ecology. Didymozoids are likely the most useful group to be used as tags, because they are permanent parasites and because of their site specificity, but also $P$. appendiculatus can be used with some caution. The main drawback of the use of didymozoids as tags is the limited knowledge of their taxonomy (Mladineo et al. 2010). Therefore, the first step crucial to allow effective these parasites as tags is to deepen the knowledge of their taxonomy, biology and ecology.

Acknowledgements. We thank Giuliano Greco (Ligure Sarda Company, Carloforte, Italy), the 'tonnarotti' fishermen of the Isola Piana and Portoscuso traps, and Paolo Sala (Fishing Center IGFA, Porto Ottiolu, Italy) for their collaboration during sampling. We are grateful to Leslie Chisholm (South Australian Museum, Adelaide, South Australia) and Francisco E. Montero (University of Valencia, Valencia, Spain) for taxonomic advice, and M. Grazia Pennino (Centro Oceanográfico de Murcia, IEO, San Pedro del Pinatar, Spain) for advice on statistical analysis. We thank two anonymous reviewers and the editors for their criticism and suggestions. This research was supported by Assessorato Difesa Ambiente RAS No. 32688-49-30.12.08, Fondazione Banco di Sardegna 2010 and the Spanish Government project PARATUN AGL2010-20892.

\section{REFERENCES}

Addis P., Dean J.M., Pesci P., Locci I., Cannas R., Corrias S., CAU A. 2008: Effects of local scale perturbations in the Atlantic bluefin tuna (Thunnus thynnus L.) trap fishery of Sardinia (W. Mediterranean). Fish. Res. 92: 242-254.

Addis P., Secci M., Locci I., Cau A., Sabatini A. 2012: Analysis of Atlantic bluefin tuna catches from the last tonnara in the Mediterranean Sea: 1993-2010. Fish. Res. 127-128: 133-141.

Aiken H., Bott N.J., Mladineo I., Montero F.E., Nowak B.F., HAYWARD C.J. 2007: Molecular evidence for cosmopolitan dis- tribution of platyhelminth parasites of tunas (Thunnus spp.). Fish Fish. 8: 167-180.

Ariola V. 1902: Contributo per una monografia dei Didymozoon. I Didymozoon parassiti del tonno. Arch. Parasitol. 6: 99-108.

BAKus G.J. 2007: Quantitative Analysis of Marine Biological Communities: Field Biology and Environment. Wiley-Interscience, Hoboken, New Jersey, 435 pp.

Brian A. 1906: Copepodi Parassiti dei Pesci d'Italia. Ist. Sordomuti Genova, 240 pp. 
Bush A.O., Lafferty K.D., Lotz J.M., Shostak A.W. 1997: Parasitology meets ecology on its own terms: Margolis et al. revisited. J. Parasitol. 83: 575-583.

Chao A., Chazdon R.L., Colwell R.K., Shen T. 2005: A new statistical approach for assessing similarity of species composition with incidence and abundance data. Ecol. Lett. 8: 148-159.

Chisholm L.A., Whittington I.D. 2007: Review of the Capsalinae (Monogenea: Capsalidae). Zootaxa 1559: 1-30.

Chow S., Kishino H. 1995: Phylogenetic relationships between tuna species of the genus Thunnus (Scombridae: Teleostei): inconsistent implications from morphology, nuclear and mitochondrial genomes. J. Mol. Evol. 41: 741-748.

Cressey R., Cressey H.B. 1980: Parasitic copepods of mackerel and tuna-like fishes (Scombridae) of the world. Smiths. Contrib. Zool. 311: 1-186.

Dalirsefat S., Meyer A., Mirhoseini S. 2009: Comparison of similarity coefficients used for cluster analysis with amplified fragment length polymorphism markers in the silkworm, Bombyx mori. J. Insect Sci. 9: 71-79.

Damanaki M. 2010: Commission Decision of 6 April 2010 amending Decision 2009/296/EC establishing a specific control and inspection programme related to the recovery of bluefin tuna in the Eastern Atlantic and the Mediterranean. European Commission, 6 April 2010, Brussels, Belgium, p. 1.

De la Serna J.M, Alot E., Majuelos E., Rioja P. 2004: La migración trófica post-reproductiva del atún rojo (Thunnus thynnus) a través del estrecho de Gibraltar. In: Proceedings of the Bluefin Year Program (BYP), Madrid, Spain, 15-16 May 2003. Col. Vol. Sci. Pap. ICCAT 56: 1196-1209.

FAO 2010: FAO Fisheries Department, Fishery Information, Data and Statistics Unit. FISHSTAT Plus: Universal software for fishery statistical time series. Version 2.3.

Fromentin J.M., Powers J.E. 2005: Atlantic bluefin tuna: population dynamics, ecology, fisheries and management. Fish Fish. 6: 281-306.

Garibaldi L., CAdDY J.F. 1998: Biogeographic characterization of Mediterranean and Black Sea faunal provinces using GIS procedures. Ocean Coast. Manag. 39: 211-227.

GuiarT J. 1938: Trématodes parasites provenait des campagnes scientifiques du Prince Albert 1 de Monaco (1886-1912). Res. Camp. sci. Monaco 100: 1-75.

Hayward C.J., Aiken H.M., Nowak B.F. 2007: Metazoan parasites on gills of southern bluefin tuna (Thunnus maccoyii) do not rapidly proliferate after transfer to sea cages. Aquaculture 262: $10-16$.

Hogans W.E. 1985: Occurrence of Caligus coryphaenae (Copepoda, Caligidae) on the Atlantic bluefin tuna (Thunnus thynnus L.) from Prince Edward Island, Canada. Crustaceana 49: 313-314.

Ishi N. 1935: Studies on the family Didymozoidae (Monticelli, 1888). Jpn. J. Zool. 6: 279-335.

Jones J.B. 1991: Movements of albacore tuna (Thunnus alalunga) in the South Pacific: evidence from parasites. Mar. Biol. 111: $1-9$.

Kabata Z. 1992: Copepods parasitic on fishes. Keys and notes for identification of the species. Synopsis of the British Fauna, New Series 47: 1-264.

KaraKUlaK F.S., ORAY I.K. 2009: Remarks on the fluctuations of bluefin tuna catches in Turkish waters. In: Proceedings of the World Symposium for the Study into the Stock Fluctuation of Northern Bluefin Tunas (Thunnus thynnus and Thunnus orientalis), Including the Historical Periods, Santander, Spain, 22-24 April 2008. Col. Vol. Sci. Pap. ICCAT 63: 153-160.
Lardeaux F. 1982: Étude de la structure des populations d'albacores (Thunnus albacares) dans l'Atlantique tropical par l'analyse des chiffres d'infestations parasitaire. In: Proceeding of the 1981 Inter-Sessional SCRS Officers Meeting, Miami, Florida, 11 June 1981. Col. Vol. Sci. Pap. ICCAT 17: 68-74.

Lester R.J.G., Barnes A., Habib G. 1985: Parasites of skipjack tuna, Katsuwonus pelamis: fishery implications. Fish. Bull. 83: 343-356.

MacKenzie K. 1983: The selection of parasites for use as biological tags in population studies of bluefin tuna. In: Proceedings of the 1982 SCRS Officers Meeting "General Statistics and Methods of Population Analysis". Col. Vol. Sci. Pap. ICCAT 18: 834-838.

MacKenzie K., Abaunza P. 1998: Parasites as biological tags for stock discrimination of marine fish: a guide to procedures and methods. Fish. Res. 38: 45-56.

MagurRan A.E. 2004: Measuring Biological Diversity. WileyBlackwell, New York, 264 pp.

Mele S., Macías D., Gómez M.J., Garippa G., Alemany F., Merella P. 2012: Metazoan parasites on the gills of the skipjack tuna Katsuwonus pelamis (Osteichthyes: Scombridae) from the Alboran Sea (western Mediterranean Sea). Dis. Aquat. Org. 97: 219-225.

Mele S., Merella P., Macías D., Gómez M.J., Garippa G., Alemany F. 2010: Metazoan gill parasites of wild albacore Thunnus alalunga (Bonaterre, 1788) from the Balearic Sea (western Mediterranean) and their use as biological tags. Fish. Res. 102: 305-310.

Mladineo I. 2006: Histopathology of five species of Didymocystis spp. (Digenea: Didymozoidae) in cage-reared Atlantic bluefin tuna (Thunnus thynnus thynnus). Vet. Res. Commun. 30: $475-484$

Mladineo I., Bott N.J., Nowak B.F., Block B.A. 2010: Multilocus phylogenetic analyses reveal that habitat selection drives the speciation of Didymozoidae (Digenea) parasitizing Pacific and Atlantic bluefin tunas. Parasitology 137: 1013-1025.

Mladineo I., Segvić T, Petrić M. 2011: Do captive conditions favor shedding of parasites in the reared Atlantic bluefin tuna (Thunnus thynnus)? Parasitol. Int. 60: 25-33.

Mladineo I., Žilić J., Čanković M. 2008: Health survey of Atlantic bluefin tuna, Thunnus thynnus (Linnaeus, 1758), reared in Adriatic cages from 2003 to 2006. J. W. Aquac. Soc. 39: 281-289.

Momoyama K., Kobayashi T. 2004: [Didymozoid parasites found in the bluefin tuna, Thunnus thynnus, caught in the coastal waters along Yamaguchi Prefecture in the Japan Sea.] Bull. Yamaguchi Prefect. Fish Res. Center 2: 125-142. (In Japanese.)

Nowak B., Mladineo I., Aiken H., Bott N., Hayward C. 2006: Results of health surveys of two species of farmed tuna: southern bluefin tuna (Thunnus maccoyii) in Australia and northern bluefin tuna (Thunnus thynnus) in the Mediterranean. Bull. Eur. Ass. Fish Pathol. 26: 38-42.

Palombi A. 1949: I trematodi d'Italia. Parte I. Trematodi monogenetici. Arch. Zool. Ital. 34: 204-408.

PozDnyakov S.E. 1990: [Revision of the genus Didymocystis and validation of the genus Didymosulcus gen. n. (Trematoda: Didymozoidae).] Zool. Zh. 69: 5-11. (In Russian)

Pozdnyakov S.E., Gibson D.I. 2008: Family Didymozoidae Monticelli, 1888. In: R.A. Bray, A. Jones and D.I. Gibson (Eds.), Keys to the Trematoda. Vol. 3. CABI, Wallingford, pp. 631-734.

R Development Core Team, 2012: R: a language and environment for statistical computing. R Foundation for Statistical 
Computing. Vienna, Austria. ISBN 3-900051-07-0, URL http:// www.R-project.org/.

Reiczigel J., Rózsa L. 2005: Quantitative Parasitology 3.0. Budapest. Distributed by the authors.

Rodríguez-Marín E., Barreiro S., Montero F.E., Carbonell E. 2008: Looking for skin and gill parasites as biological tags for Atlantic bluefin tuna (Thunnus thynnus). Aquat. Liv. Resour. 21: $365-371$

Rooker J.R., Secor D.H., Zdanowicz V.S., De Metrio G., Orsi ReLini L. 2003: Identification of Atlantic bluefin tuna (Thunnus thynnus) stocks from putative nurseries using otolith chemistry. Fish. Oceanogr. 12: 75-84.

Rooker J.R., Bremer J.R.A., Block B., Dewar H., de Metrio G., Corriero A., Kraus R., Prince E., Rodríguez-Marín E., Secor D. 2007: Life history and stock structure of Atlantic bluefin tuna (Thunnus thynnus). Rev. Fish. Sci. 15: 265-310.

Ruiz de Ybañez R., Peñalver J., Martínez-Carrasco C., del Río L., Dolores E.M., Berriatua E., Muñoz P. 2011: Blood fluke infection of cage reared Atlantic bluefin tuna Thunnus thynnus in west Mediterranean. Fish Pathol. 46: 87-90.

Silas E.G. 1962: Parasites of scombroid fishes. Part I. Monogenetic trematodes, digenetic trematodes, and cestodes. In: Proceedings of the Symposium on Scombroid Fishes, Part 3, Mar. Biol. Assoc. India Mandapam, Tamil Nadu, India, 12-15 January 1962 , pp. $799-875$.
Silas E.G., Ummerkutty A.N.P. 1967: Parasites of scombroid fishes Part II: Parasitic Copepoda. In: Proceedings of the Symposium on Scombroid Fishes, Part 3, Mar. Biol. Assoc. India, Mandapam, Tamil Nadu, India, 12-15 January 1962, pp. 876993.

Sorell G.M. 2012: Prospecciones aéreas en el Mediterráneo Occidental durante la concentración de juveniles de atún rojo (Thunnus thynnus) en el Golfo de León. In: Proceedings of the 2011 GBYP Workshops on Aerial Surveys, and Operational Meetings on Biological Sampling and on Tagging of Bluefin Tuna, Madrid, Spain, 14-18 February 2011. Col. Vol. Sci. Pap. ICCAT 68: 73-97.

Tudela S., Hidas E., Graupera E., Sainz Trápaga S., Cermeño P., Quílez-Badia G. 2011: Bluefin tuna migratory behaviour in the western and central Mediterranean Sea revealed by electronic tags. In: Proceedings of the 2010 Atlantic Bluefin Tuna Stock Assessment Session, Madrid, Spain, 6-12 September 2010. Col.Vol. Sci. Pap. ICCAT 66: 1157-1169.

WALTERS V. 1980: Ectoparasites of eastern and western Atlantic bluefin tuna. In: Proceedings of the 1979 SCRS Officers Meeting "General Statistics And Methods Of Population Analysis", Las Palmas, Spain, 26-28 July 1979. Col. Vol. Sci. Pap. ICCAT 9: 491-498.

Yamaguti S. 1970: Digenetic Trematodes of Hawaiian Fishes. Interscience Publishers, New York, 436 pp.

Accepted 13 September 2013 